\title{
APLIKASI RHIZOBIUM DAN CENDAWAN MIKORIZA ARBUSCULA (CMA) TERHADAP PERTUMBUHAN TANAMAN KACANG TANAH (Arachis hypogeal) DI DESA SOCAH KECAMATAN SOCAH KABUPATEN BANGKALAN MADURA
}

\author{
Tutik Nurhidayati ${ }^{1}$, Nurul Jadid ${ }^{1}$, dan Safita Meridian² \\ 1Jurusan Biologi FMIPA - ITS \\ 2 Dinas Pertanian Bangkalan \\ tutik@bio.its.ac.id
}

\begin{abstract}
The cultivation of peanuts in Socah village mostly located in marginal land. On the other hand to increase the productivity of land by local communities is use of chemical fertilizers. The effects of chemical fertilizers is the decline in the productivity of the land. In these circumstances it is absolutely necessary to perfect technology of dry land resources is essential. One of the technologies that can be developed is the use of rhizobium and mycorrhiza. Thus occurred the tripartite relationship between rhizobium, mycorrhiza, and plants arbuscula beneficial for growth and development of land. In this study the application of local rhizobium and mycorrhiza on crops of peanuts, with measurable parameters of nodule formation and detection of plant growth and productivity of peanut.
\end{abstract}

Key words: Mycorrhiza Arbuscula, peanut, rhizobium, Socah village.

\section{PENGANTAR}

Salah satu daerah di Jawa Timur yang mempunyai komoditas pertanian tanaman pangan unggulan dan dapat dikembangkan adalah Kabupaten Bangkalan Pulau Madura Jawa Timur. Desa Socah, Kecamatan Socah Kabupaten Bangkalan merupakan sentral pengembangan tanaman pangan kacang tanah dengan luas panen bersih lebih dari 1.650 hektar dengan total produksi 34.993 ton dan rata-rata produksi lebih dari 12,89 kw/ha (Anonimus, 2008).

Berdasarkan data yang diperoleh oleh peneliti pada tahun 2009, sebagian besar lahan yang digunakan untuk budidaya kacang tanah di kabupaten Bangkalan termasuk kategori lahan yang kurang subur dan ketersediaan air yang rendah (jenis tanah berkapur, kandungan N, P, dan K rendah, serta kadar air rendah $\pm 16,18 \%$ ), namun mikroorganisme lokal seperti mikoriza mempunyai keragaman dan diversitas yang cukup tinggi (Nurhidayati, 2009). Di sisi lain peningkatan produktivitas lahan yang dilakukan oleh masyarakat setempat adalah pemakaian pupuk buatan atau pupuk kimia. Efek yang ditimbulkan akibat pemakaian pupuk kimia adalah efektivitas rendah karena memerlukan biaya tinggi, pada rentang waktu tertentu tingkat produktivitas lahan menurun dan seringkali menyebabkan pencemaran lingkungan yang berakibat lebih jauh terjadinya degradasi kualitas lahan dan kualitas lingkungan (Prihastuti, 2007).

Dalam kondisi seperti ini mutlak diperlukan adanya penajaman teknologi sumberdaya lahan kering-kritis.
Salah satu teknologi yang dapat dikembangkan adalah pemanfaatan rhizobium dan mikoriza.

Teknik ini memberikan manfaat pada tanaman untuk dapat tumbuh dan berproduksi dengan baik pada lahan kurang subur melalui peningkatan ketersediaan unsur hara bagi tanaman, perbaikan kesuburan lahan, dan peningkatan daya tahan pada kekeringan. Keuntungan lain pemanfaatan teknik tersebut adalah: (a) tidak mempunyai bahaya atau efek sampingan, (b) efisiensi penggunaan yang dapat ditingkatkan sehingga bahaya pencemaran lingkungan dapat dihindari, (c) harganya yang relatif murah, dan (d) teknologinya yang sederhana (Suhardi, 1990).

\section{BAHAN DAN CARA KERJA}

\section{Perbanyakan Inokulan Mikoriza Lokal (CMA) dan Penyemaian Bibit}

Salah satu teknik yang dapat digunakan untuk memperoleh inokulan CMA dalam jumlah banyak melalui perbanyakan pada tanaman jagung. Media yang digunakan untuk memperbanyak inokulan CMA pada jagung adalah tanah mediteran yang telah disterilkan sebanyak $10 \mathrm{~kg}$ tanah dalam setiap polybag, dengan ukuran polybag $30 \mathrm{~cm} \times$ $40 \mathrm{~cm}$. Masing-masing diisi satu tanaman. Tanaman jagung yang bermikoriza (umur 2 Bulan) dalam polybag tersebut selanjutnya dilakukan dilakukan stressing selama 3 sampai 4 minggu. Setelah dilakukan stressing atau tanaman telah mati dan media kering, batang tanaman dipotong. Media 
tanam dalam pot dibongkar dan akar tanam dipotong pendek-pendek kurang lebih $1 \mathrm{~cm}$ kemudian dicampur dengan media tanam. Inokulan ini siap dipakai sebagai biofertilizer. Benih kacang tanah direndam selama 24 jam, kemudian diatuskan. Pada perlakuan inokulasi dengan rhizobium, setelah diatuskan benih dicampur dengan legin (rhizobium) dengan dosis $150 \mathrm{~g} / 15 \mathrm{~kg}$. Benih kacang tanah tersebut selanjutnya siap disemaikan ke dalam media tanam (lahan).

\section{Inokulasi Mikorhiza Indigenous dan Mikorhiza Jadi}

Inokulasi mikoriza dilakukan dengan menggunakan sistem lapisan. Media perkecambahan yang telah disterilkan dimasukkan pada bak perkecambahan dengan ketebalan $10 \mathrm{~cm}$, kemudian di atasnya dilapisi dengan inokulan mikoriza setebal $1 \mathrm{~cm}$ dan dilapisi lagi dengan media steril setebal $0,25 \mathrm{~cm}$. Pada lapisan tersebut benih yang sudah diisolasi rhizobium ditaburkan secara merata, kemudian ditutup dengan media steril setebal $0,5 \mathrm{~cm}$ dan disiram dengan air. Selanjutnya benih yang telah diperlakukan ditanam dalam lahan sesuai dengan perlakuan. Perlakuan yang dilakukan dalam penelitian ini ada 5 macam, yaitu:

I : Perlakuan Mikoriza Indigenous

II : Perlakuan Rhizobium

III : Perlakuan Rhizobium dan Indigenous

IV : Perlakuan Kontrol

V : Perlakuan Mikorhiza Jadi

Tanaman yang telah ditanam dibiarkan tumbuh sampai masa tanam, kurang lebih selama 2,5 bulan dengan parameter terukur, meliputi:

\section{a. Tinggi Tanaman (cm)}

Tinggi tanaman kacang tanah diukur dari permukaan tanah sampai percabangan terakhir.

b. Berat Bintil Akar (gram)

Berat bintil akar ditentukan berdasarkan berat kering udara.

c. Berat Kering Tanaman (gram)

Bahan tanaman dikeringkan dalam oven dengan temperatur $110^{\circ} \mathrm{C}$ sampai beratnya konstan. Berat yang sudah konstan kemudian ditimbang dengan neraca elektrik.

\section{d. Produktivitas Tanaman (gram)}

Produktivitas tanaman yang terukur adalah buah kacang tanah perluasan media tanam.

\section{HASIL}

Rerata tinggi tanaman kacang tanah di desa Socah Kecamatan Socah Kabupaten Bangkalan Madura Jawa Timur ditampilkan Pada Gambar 1. Rerata berat kering bintil akar pada tanaman kacang tanah ditunjukkan pada Gambar 2. Rerata berat kering tanaman kacang tanah di Desa Socah Kecamatan Socah Kabupaten Bangkalan Madura ditampilkan dalam Gambar 3. Rerata Produktivitas tanaman kacang tanah (usia 5 Minggu Hari setelah Tanam) yang berupa buah pada beberapa perlakuan ditunjukkan pada Gambar 4.

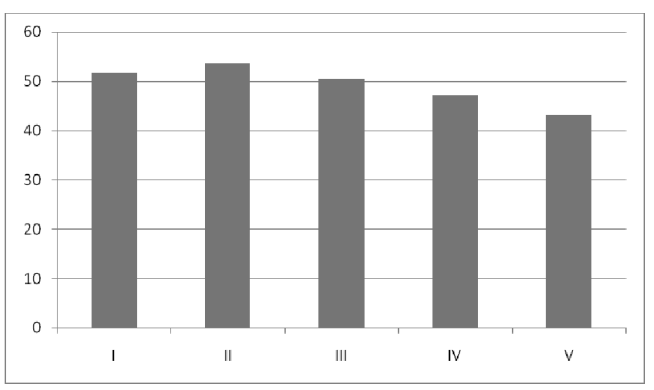

Gambar 1. Rerata Tinggi Tanaman Kacang Tanah Pada Beberapa Perlakuan

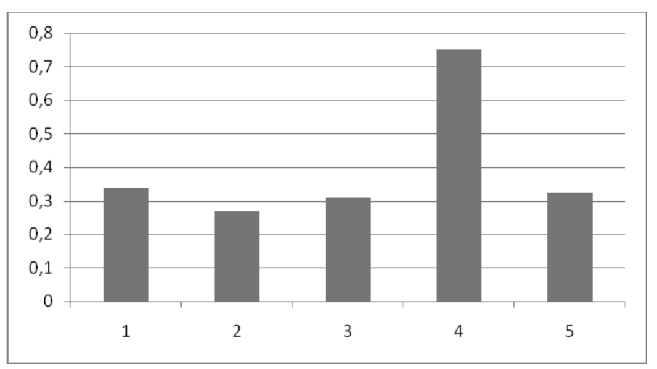

Gambar 2. Rerata Berat Bintil Akar Tanaman Kacang Tanah di BeberapaPerlakuan

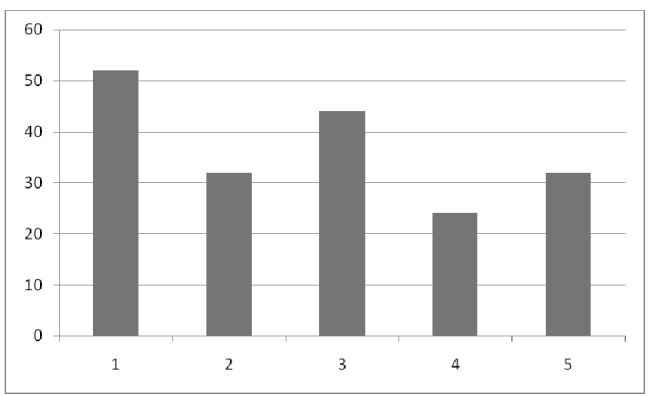

Gambar 3. Rerata Berat kering Tanaman Kacang Tanah Pada Beberapa Perlakuan 


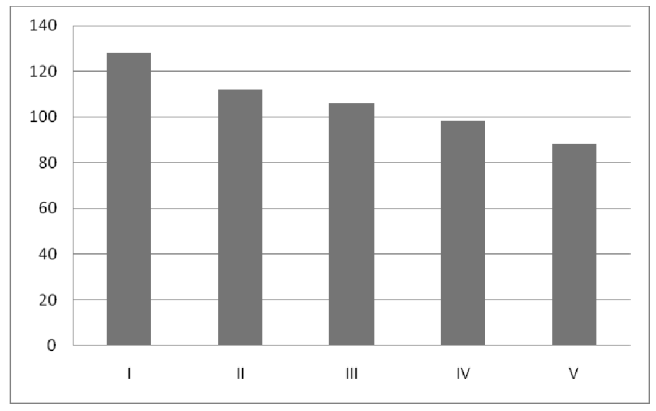

Gambar 4. Rerata Produktivitas Tanaman Kacang Tanah Pada Beberapa Perlakuan

\section{PEMBAHASAN}

Berdasarkan Gambar 1 dapat terlihat bahwa tanaman yang diberi perlakuan mikoriza indigenous, rhizobium, dan keduanya menunjukkan rerata lebih tinggi dari aplikasi mikoriza yang jadi maupun kontrol. Hal ini menunjukkan bahwa asal isolat yaitu mikoriza indigenous yang diisolasi dari perakaran kacang tanah dan daerah setempat, yang selanjutnya diperbanyak pada media buatan memberikan respon positif terhadap tingi tanaman inang. Respon positif tersebut dikarenakan kondisi lingkungan tanah cocok untuk perkecambahan biji dan perkecambahan spora CAM. Demikian pula kondisi edafik yang dapat mendorong pertumbuhan akar, sesuai juga untuk perkembangan hifa CAM (Paulitz and Linderman, 1991). Sedangkan pada aplikasi mikoriza yang sudah jadi rerata tinggi tanaman inang, yaitu kacang tanah menunjukkan rerata yang paling rendah. Hal ini disebabkan kondisi lingkungan dan kondisi edafik yang berbeda mempengaruhi keberhasilan perkecambahan dan efektifitas spora CAM.

\section{Berat Bintil Akar}

Berdasarkan Gambar 2 terlihat bahwa tanaman dengan adanya aplikasi mikoriza jadi, mikoriza indigenous, rhizobium, dan keduanya menunjukkan rerata lebih rendah dari kontrol. Kondisi tersebut diduga karena ada persaingan antar mikroba dalam media tumbuh, yaitu persaingan mikroba eksogen dengan mikroba endogen. Bentuk persaingan ini dapat berupa persaingan dalam merebutkan ruang, air, dan unsur-unsur hara, serta infeksi di daerah perakaran tanaman inang. Inokulasi mikoriza maupun rhizobium eksogen secara tidak langsung ke media tumbuh adalah inokulasi strain baru. Menurut Killham (1999), Mishra dkk. (1999) dan Lupwayi dkk. (1997), faktor strain mikrobia merupakan salah satu faktor yang ikut menentukan kemampuan mikrobia dalam melakukan persaingan. Kemampuan dalam bersaing ini akhirnya dapat meningkatkan jumlah serta berat bintil akar. Persaingan diantara mikroba eksogen dan mikroba endogen biasanya akan didominasi oleh mikroba endogen, karena telah teradaptasi pada media tumbuh sebelumnya.

\section{Berat kering Tumbuhan}

Berdasarkan Gambar 3 dapat, terlihat bahwa kontrol menunjukkan berat kering terendah dibanding perlakuan lainnya. Hal ini menunjukkan bahwa adanya aplikasi mikrobia eksogen berupa mikoriza dan rhizobium atau keduanya dapat meningkatkan pertumbuhan atau hasil tanaman kacang tanah, meskipun pembentukan bintil akar rendah (berdasarkan rerata berat bintil akar).

Peningkatan hasil yang diasumsikan dengan peningkatan berat kering berhubungan dengan hasil fotosintesis yang ditimbun dalam tanaman. Fotoasimilat, unsur hara, dan asam amino yang dibutuhkan untuk permulaan pertumbuhan vegetatif dan kolonisasi mikrobia disediakan oleh tanaman inang tanpa adanya keuntungan bagi tanaman. Selanjutnya, tercukupinya kebutuhan energi bagi mikrobia dari tanaman inang akan meningkatkan kolonisasi mikrobia. Kolonisasi mikrobia (mikoriza dan rizobium) ini akan memberikan peran positif dalam penyediaan unsur hara terutama unsur $\mathrm{N}$ dan P serta air. Pertumbuhan merupakan manifestasi dari banyak proses yang dimulai dari penyediaan karbohidrat dari organ fotosintesis dan penyediaan air dan unsur hara oleh akar sampai kepada sintesis biomassa bahan baru atau biomassa tanaman. Akhirnya, peningkatan laju fotosintesis akan meningkatkan penyerapan hara tanaman, pertumbuhan tanaman yang diwujudkan kedalam produksi biomassa tanaman atau berat kering tanaman.

\section{Produktivitas Tanaman}

Berdasarkan Gambar 4 diketahui bahwa perlakuan dengan aplikasi mikoriza indigenous dan interaksi ganda dengan rhizobium memberikan hasil lebih tinggi dibanding kontrol. Hasil ini diperkuat dengan data tinggi tanaman bahwa adanya introduksi mikrobia eksogen terutama dengan adanya aplikasi mikoriza indigenous dapat meningkatkan pertumbuhan tanaman termasuk hasil/produktivitasnya. Peningkatan pertumbuhan tanaman dengan adanya aplikasi mikrobia eksogen berupa mikorhiza indigenous dan rhizobium disebabkan oleh struktur yang terbentuk akibat kerjasama yang saling menguntungkan antara mikroorganisme tanah dengan akar tanaman dalam meningkatkan masukan air dan hara dari tanah ke dalam jaringan tanaman serta adanya perlindungan akar tanaman dari serangan patogen yang menyebabkan penyakit terbawa tanah atau Soil-born Diseases. Lebih 
lanjut hasil penelitian Saptiningsih (2001) menunjukkan bahwa pemanfaatan mikrobia eksogen ke media tumbuh tanaman dapat meningkatkan pertumbuhan dan hasil/ produktivitas tanaman.

\section{KEPUSTAKAAN}

Anonimus, 2008. Laporan Profil Daerah Di Jawa Timur. Dinas Pertanian Tanaman Pangan Jawa Timur, Surabaya.

Killham K, 1999. Soil Ecology. Cambridge University Press. New York.

Lupwayi NZ, Haque I, dan Holl FB, 1997. Effectiveness, Competiveness, and Persistence of Inoculant Rhizobium for Perenmial African Clovers in a Highland Vertisol. Journal Agriculture Science.

Mishra SN, Jaiwal PK, Singh RP, dan Srivasta HS, 1999. Rhizobium-Legume Association dalam Srivasta dan RN Sing (Eds.), Nitrogen Nutrition and Plant Growth. Science Publisher. Inc. USA.
Nurhidayati T, 2009. Aplikasi Bioteknologi Cendawan Mikoriza Arbuscular (CMA) Pada Lahan Kering Untuk Pengembangan Potensi Komoditas Unggulan Tabnaman Pangan dan Buah di Jawa Timur. Penelitian Stranas ITS. Institut Teknologi Sepuluh Nopember. Surabaya.

Paulitz TC and Linderman RG, 1991. Mycorrhizal Interaction with Soil Organisms. dalam DK Arora dkk. (Eds.), Handbook of Applied Mycology: Soil And Plants, Volume I. Marcel Dekker. Inc. New York.

Prihastuti, 2007. Isolasi dan karakterisasi Mikoriza VesikularArbuskular di Lahan Kering Masam, Lampung Tengah. Berkala Penelitian Hayati. 12 (99-106).

Suhardi, 1990. Mikorhiza V.A., PAU-Bioteknologi. Universitas Gadjah Mada. Yogyakarta.

Saptiningsih E, 2001. Pertumbuhan Vigna radiate L. Wilezeck dalam Persaingan dengan Cyperus rotundus L. pada Perlakuan Inokulasi Rhizobium dengan Mikorhiza Arbuskula. Fakultas Biologi. Program Pascasarjana Universitas Gajah Mada. Yogjakarta. 